Original Research

\title{
Radioactivity in Kosovo Honey Samples
}

\author{
Serdar Dizman', Gezim Hodolli²*, Sehad Kadiri ${ }^{3}$, Hamdi Aliu ${ }^{4}$, Sami Makolli ${ }^{5}$ \\ ${ }^{1}$ Department of Physics, Faculty of Arts and Sciences, Recep Tayyip Erdogan University, Rize, Turkey \\ ${ }^{2}$ University for Business and Technology UBT, Pristina, Kosovo \\ ${ }^{3}$ AAB College, Pristina, Kosovo \\ ${ }^{4}$ Faculty of Agriculture and Veterinary, University of Pristina, Pristina, Kosovo \\ ${ }^{5}$ University for Business and Technology UBT, Pristina, Kosovo
}

Received: 27 September 2018

Accepted: 26 March 2019

\begin{abstract}
The aim of this study was to determine naturally occurring radionuclides $\left({ }^{40} \mathrm{~K},{ }^{226} \mathrm{Ra}\right.$ and $\left.{ }^{232} \mathrm{Th}\right)$ and the artificial radionuclide ${ }^{137} \mathrm{Cs}$ in various honey samples from Kosovo. This study is of particular importance because it is the first effort to evaluate contamination of honey samples by radioactivity at the country level. The average radioactivity concentrations of ${ }^{226} \mathrm{Ra},{ }^{232} \mathrm{Th},{ }^{137} \mathrm{Cs}$ and ${ }^{40} \mathrm{~K}$ radionuclides on honey samples were found to be $0.49 \pm 0.15,1.28 \pm 0.18,1.03 \pm 0.11$ and $20.44 \pm 0.69 \mathrm{~Bq} \mathrm{~kg}^{-1}$, respectively. The activity values of ${ }^{137} \mathrm{Cs}$ found in honey samples were well below the limit value $\left(1000 \mathrm{~Bq} \mathrm{~kg}^{-1}\right)$ recommended by the ICRP in foodstuffs. Only $20 \%$ of honey samples were found to be contaminated with artificial isotopes ${ }^{137} \mathrm{Cs}$, and activities proved that the Chernobyl radiocaesium presents no risk to public health. Our study confirms that the honeys produced in Kosovo are of good quality and are in line with international standards due to radioactivity concentration. So it is a healthy food for consumption.
\end{abstract}

Keywords: radioactivity, honey, bee, daily intake, lifetime cancer risk, public health

\section{Introduction}

Honey is a natural food that is widely used in human daily life. Honey is produced by Apis mellifera (Genus name) from flower nectar or honeydew. It has been proven that honey has many health benefits for humans $[1,2]$. From different authors, honey is classified as an antioxidant and anti-bacterial [3-5]. Also, publications have shown direct benefits given by honey to radiotherapy patients $[6,7]$ and for skin care [8]. Honey is used also as a bio indicator of the environment $[9,10]$. Also, it is documented that honey contains chemical

*e-mail: g.hodolli@hotmail.com components of plants. Honeybees collect their pollen and nectar all around the environment, so the content of elements and their quantity present in honey depends on environmental conditions [11]. Uranium and thorium are two naturally occurring radioactive elements in the environment. These isotopes and their radioactive decay products are transferred to water and plants from soil, then to humans by ingestion route [12]. According to this paragraph, many researchers have proposed using honey as an environmental bio-indicator.

Honeybees interact strongly with vegetables, air, soil, and water in the vicinity of the hive and, as a consequence, pollutants from these sources are translated to the honeybees and to the hive products [13]. On this basis, radioactivity concentration on honey should be linked directly to the quality of environment 
bees collect nectar from plants and flowers. Nuclear accidents and nuclear tests have happened around the world and artificial radiation has been detected in Kosovo - especially from the nuclear power plant accident in Chernobyl [14]. Among other things, radioactivity in various honey samples is analyzed by different authors. They found contamination of honey samples by natural and artificial radioactivity [15-17].

The aim of this study was the determination of natural radionuclides: ${ }^{40} \mathrm{~K},{ }^{226} \mathrm{Ra}$ and ${ }^{232} \mathrm{Th}$ and artificial radionuclide ${ }^{137} \mathrm{Cs}$, then to find if there is variation of radionuclide concentrations within honey samples at the same place in order to calculate the annual effective dose, total committed effective dose and the lifetime cancer risk, and to compile a database for radioactivity levels in the Republic of Kosovo. This investigation was conducted in 2018 in the Republic of Kosovo in southeastern Europe - more specifically in the center of the Balkan Peninsula.

\section{Material and Methods}

To have homogeneous sampling process in an entire country we chose the systematic gird square sampling pattern method. The territory of Kosovo was divided into 30 equal surface units with rectangular shape, as shown in Fig. 1. One cell represents around $363 \mathrm{~km}^{2}$ and in each of them we took one honey sample for further analysis. Honey is useful for collecting information about the environment within the bees "collecting area", which is about $7 \mathrm{~km}^{2}$ [18].

Samples of honey from 30 apiaries were selected to participate to this survey. Geographical sample locations were recorded by portable GPS during the sampling time, and a digital map with sampling location is prepared by MapInfo Professional software. Honey samples are collected in $200 \mathrm{~g}$ plastic containers. Radioactivity levels of each honey sample were examined and for comparison reasons, analysis is done on the basis of Kosovo regions (Ferizaj, Gjakova, Gjilani, Mitovica, Peja, Prishtina and Prizreni).

The radiation levels of samples were analyzed using gamma spectrometry using a 55\% efficiency high-purity germanium (ORTEC HPGe, model No. GEM55P4-95) detector and a multichannel analyzer. The resolution (full width half maximum) of this detector system was $1.0 \mathrm{keV}$ for $122 \mathrm{keV}$ gamma ray of ${ }^{57} \mathrm{Co}$ and $1.9 \mathrm{keV}$ for $1332 \mathrm{keV}$ gamma ray of ${ }^{60} \mathrm{Co}$. The detector was shielded in a cylindrical lead shield of $10 \mathrm{~cm}$ thickness to reduce the background level of the system. Efficiency of the detector was determined with a ${ }^{152} \mathrm{Eu}$ source with known activity. ${ }^{152} \mathrm{Eu}$ sources have been widely used for calibration and efficiency determination because of their large range of energies $(122,244,344,411,443,779$, 964,1112 and $1408 \mathrm{keV}$ ) with emission probabilities of $3-29 \%$ [19]. An ideal measuring geometry of cylindrical source (homogeneously distributed activity with

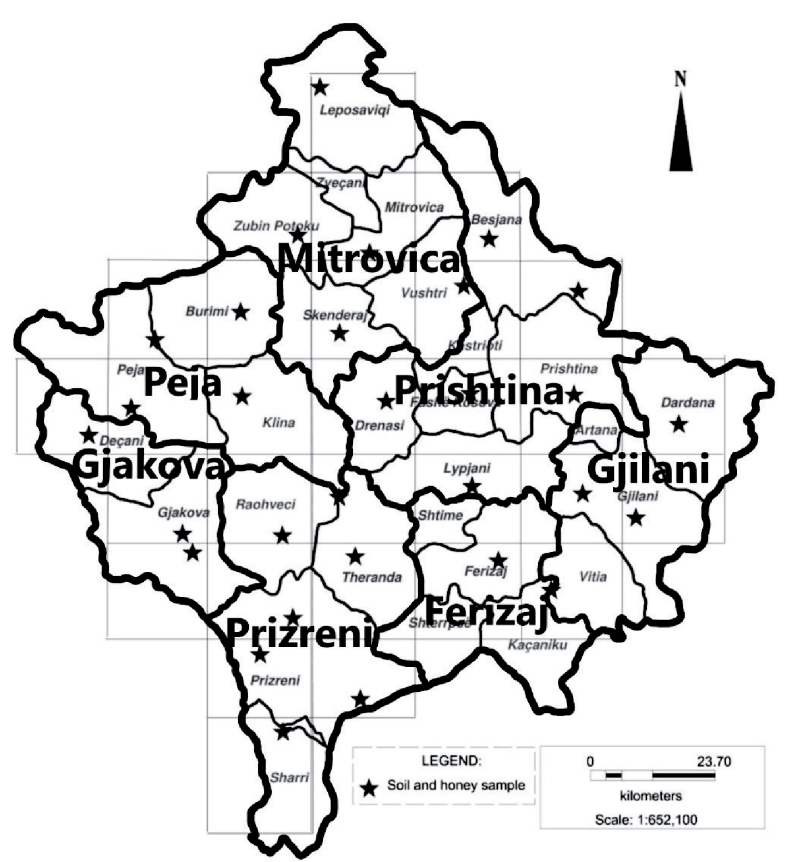

Fig. 1. Regions of Kosovo and honey sampling sites.

constant volume and distance) was placed coaxially with the detector for the efficiency determination and the same procedure applied for the sample measurements.

The activity concentrations of ${ }^{226} \mathrm{Ra}$ were determined by averaging the measured concentrations for ${ }^{214} \mathrm{~Pb}$ (295 and $351 \mathrm{keV}$ gamma-ray energies) and ${ }^{214} \mathrm{Bi}(609$ and $1120 \mathrm{keV}$ gamma-ray energies). The activity concentrations of ${ }^{232} \mathrm{Th}$ were determined by averaging of measured concentrations for ${ }^{212} \mathrm{~Pb}(238 \mathrm{keV}$ gamma-ray energy), ${ }^{228} \mathrm{Ac}$ (338 and $911 \mathrm{keV}$ gamma-ray energies) and ${ }^{208} \mathrm{Tl}$ (583 and keV gamma-ray energy) [20]. The activity concentration of ${ }^{40} \mathrm{~K}$ and ${ }^{137} \mathrm{Cs}$ were determined directly from the $1460 \mathrm{keV}$ and $661 \mathrm{keV}$ gamma-ray energies, respectively $[21,22]$. The gamma spectra were analyzed using Gamma Vision, which is a data acquisition and analysis program.

The samples were placed symmetrically on top of the detector and measured for a period of $80.000 \mathrm{~s}$. After measurements and subtraction of the background, the activity concentrations of the radionuclides were calculated using Equation 1.

$$
A\left(B q k g^{-1}\right)=\frac{C_{s}}{\varepsilon P_{\gamma} m t}
$$

...where $\mathrm{C}_{\mathrm{s}}$ is the count rate under the corresponding peak, $\varepsilon$ is the detector efficiency at the corresponding peak energy, $\mathrm{P}_{\gamma}$ is the absolute transition probability of the specific $\gamma$-ray at the corresponding peak energy, $\mathrm{m}$ is the mass of the sample $(\mathrm{kg})$ and $\mathrm{t}$ is the counting time (s).

The minimum detectable activity (MDA) for gamma activity measurement of the present measurement system was calculated by using Equation 2 [23, 24]: 
Table 1. Activity concentrations of ${ }^{226} \mathrm{Ra},{ }^{232} \mathrm{Th},{ }^{40} \mathrm{~K}$ and ${ }^{137} \mathrm{Cs}$ radionuclides in the honey samples.

\begin{tabular}{|c|c|c|c|c|}
\hline Sample No & ${ }^{226} \mathrm{Ra}$ & ${ }^{232} \mathrm{Th}$ & ${ }^{137} \mathrm{Cs}$ & ${ }^{40} \mathrm{~K}$ \\
\hline $\mathrm{H}-1$ & $<\mathrm{MDA}$ & $1.60 \pm 0.17$ & $0.15 \pm 0.05$ & $10.72 \pm 0.45$ \\
\hline $\mathrm{H}-2$ & $<\mathrm{MDA}$ & $0.74 \pm 0.14$ & $<\mathrm{MDA}$ or ND & $7.37 \pm 0.42$ \\
\hline $\mathrm{H}-3$ & $<\mathrm{MDA}$ & $1.02 \pm 0.18$ & $<\mathrm{MDA}$ or ND & $10.76 \pm 0.66$ \\
\hline $\mathrm{H}-4$ & $0.73 \pm 0.18$ & $1.67 \pm 0.21$ & $<\mathrm{MDA}$ or ND & $22.99 \pm 0.73$ \\
\hline H-5 & $<\mathrm{MDA}$ & $0.92 \pm 0.10$ & $2.15 \pm 0.13$ & $23.41 \pm 0.42$ \\
\hline H-6 & $<\mathrm{MDA}$ & $0.47 \pm 0.14$ & $0.25 \pm 0.08$ & $24.02 \pm 0.60$ \\
\hline $\mathrm{H}-7$ & $<\mathrm{MDA}$ & $1.55 \pm 0.18$ & $<\mathrm{MDA}$ or ND & $14.26 \pm 0.44$ \\
\hline $\mathrm{H}-8$ & $<\mathrm{MDA}$ & $2.14 \pm 0.15$ & $<\mathrm{MDA}$ or $\mathrm{ND}$ & $17.45 \pm 0.55$ \\
\hline $\mathrm{H}-9$ & $<\mathrm{MDA}$ & $0.99 \pm 0.14$ & $0.31 \pm 0.13$ & $38.81 \pm 1.20$ \\
\hline H-10 & $<\mathrm{MDA}$ & $1.91 \pm 0.13$ & $<\mathrm{MDA}$ or ND & $30.55 \pm 1.00$ \\
\hline H-11 & $0.40 \pm 0.19$ & $3.43 \pm 0.90$ & $2.80 \pm 0.17$ & $91.84 \pm 1.78$ \\
\hline H-12 & $<\mathrm{MDA}$ & $1.06 \pm 0.16$ & $<\mathrm{MDA}$ or ND & $18.12 \pm 0.59$ \\
\hline $\mathrm{H}-13$ & $<\mathrm{MDA}$ & $2.06 \pm 0.17$ & $<\mathrm{MDA}$ or ND & $10.77 \pm 0.40$ \\
\hline H-14 & $<\mathrm{MDA}$ & $1.63 \pm 0.20$ & $<\mathrm{MDA}$ or ND & $16.76 \pm 0.51$ \\
\hline H-15 & $0.55 \pm 0.14$ & $1.57 \pm 0.16$ & $<\mathrm{MDA}$ or ND & $43.36 \pm 1.21$ \\
\hline H-16 & $<\mathrm{MDA}$ & $0.68 \pm 0.14$ & $<\mathrm{MDA}$ or ND & $7.62 \pm 0.27$ \\
\hline H-17 & $<\mathrm{MDA}$ & $0.72 \pm 0.12$ & $<\mathrm{MDA}$ or ND & $7.35 \pm 0.32$ \\
\hline H-18 & $0.42 \pm 0.12$ & $0.57 \pm 0.11$ & $<\mathrm{MDA}$ or ND & $14.01 \pm 0.56$ \\
\hline H-19 & $0.67 \pm 0.11$ & $0.95 \pm 0.17$ & $<\mathrm{MDA}$ or ND & $8.67 \pm 0.26$ \\
\hline H-20 & $<\mathrm{MDA}$ & $0.80 \pm 0.11$ & $<\mathrm{MDA}$ or ND & $18.50 \pm 0.53$ \\
\hline H-21 & $<\mathrm{MDA}$ & $1.08 \pm 0.08$ & $<\mathrm{MDA}$ or ND & $7.95 \pm 0.25$ \\
\hline H-22 & $0.34 \pm 0.14$ & $1.71 \pm 0.10$ & $<\mathrm{MDA}$ or ND & $31.24 \pm 1.76$ \\
\hline H-23 & $0.61 \pm 0.19$ & $1.47 \pm 0.13$ & $<\mathrm{MDA}$ or ND & $15.37 \pm 0.34$ \\
\hline H-24 & $0.48 \pm 0.17$ & $1.05 \pm 0.14$ & $<\mathrm{MDA}$ or ND & $13.83 \pm 0.42$ \\
\hline H-25 & $0.46 \pm 0.11$ & $1.28 \pm 0.19$ & $<\mathrm{MDA}$ or ND & $9.76 \pm 0.58$ \\
\hline H-26 & $0.38 \pm 0.17$ & $0.83 \pm 0.22$ & $0.49 \pm 0.11$ & $30.50 \pm 1.36$ \\
\hline $\mathrm{H}-27$ & $0.35 \pm 0.16$ & $0.88 \pm 0.16$ & $<\mathrm{MDA}$ or ND & $12.33 \pm 0.64$ \\
\hline H-28 & $<\mathrm{MDA}$ & $0.79 \pm 0.16$ & $<\mathrm{MDA}$ or ND & $19.92 \pm 0.69$ \\
\hline H-29 & $<\mathrm{MDA}$ & $1.45 \pm 0.13$ & $<\mathrm{MDA}$ or ND & $21.54 \pm 1.36$ \\
\hline $\mathrm{H}-30$ & $<\mathrm{MDA}$ & $1.32 \pm 0.17$ & $<\mathrm{MDA}$ or ND & $13.45 \pm 0.42$ \\
\hline
\end{tabular}

MDA: Minimum Detectable Activity, ND: Not Detection

$$
M D A=\frac{2.71+4.65 \sqrt{C_{B}}}{\varepsilon P_{\gamma} m t}
$$

...where $\mathrm{C}_{\mathrm{B}}$ is the background count rate under the corresponding peak, $\mathcal{E}$ is the detector efficiency at the corresponding peak energy, $\mathrm{P}_{\gamma}$ is the absolute transition probability of the specific $\gamma$-ray at the corresponding peak energy, $\mathrm{m}$ is the mass of the sample $(\mathrm{kg})$ and $\mathrm{t}$ is the counting time (s).
The daily intake of radioactivity is considered to be an accumulation of both naturally occurring radionuclides $\left({ }^{226} \mathrm{Ra},{ }^{232} \mathrm{Th}\right.$ and $\left.{ }^{40} \mathrm{~K}\right)$ and artificial radionuclide ${ }^{137} \mathrm{Cs}$ into the human body via the consumption of food. The daily intake of natural and artificial radionuclides via the consumption of food has been calculated using Equation 3 [25]:

$$
D_{\text {int }}=\frac{A_{c} A_{i g}}{Y_{d}}
$$


...where $\mathrm{D}_{i n t}$ is the daily intake of radionuclides $\left(\mathrm{Bq} \mathrm{d}^{-1}\right)$ by individuals, $\mathrm{A}_{c}$ is the activity concentration of radionuclides $\left(\mathrm{Bq} \mathrm{kg}^{-1}\right), \mathrm{A}_{\mathrm{ig}}$ is the per capita per year consumption of honey, and $\mathrm{Y}_{d}^{\mathrm{g}}$ is the days in a year.

Honey consumption rate for the year 2016 was $1.3 \mathrm{~kg}$ per person in Kosovo [26].

The annual effective dose to an individual due to an intake of both naturally occurring radionuclides ${ }^{226} \mathrm{Ra},{ }^{232} \mathrm{Th}$ and $\left.{ }^{40} \mathrm{~K}\right)$ and artificial radionuclide $\left({ }^{137} \mathrm{Cs}\right)$ radionuclides from consumption of honey has been calculated using Equation 4 [25].

$$
H_{e f f}=A_{c} A_{i g} D_{c f}
$$

...where $\mathrm{E}_{\text {eff }}$ is annual effective dose $\left(\mu \mathrm{Sv} \mathrm{y}^{-1}\right)$ to an individual owing to an ingestion of radionuclides, $\mathrm{A}_{c}$ the average activity concentration of related radionuclide $\left(\mathrm{Bq} \mathrm{kg}^{-1}\right), \mathrm{A}_{i g}$ is the annual intake of honey $\left(\mathrm{kg} \mathrm{y}^{-1}\right)$, and $\mathrm{D}_{c f}$ is the ingestion dose conversion factor for related radionuclides $\left(2.8 \times 10^{-7} \mathrm{~Sv} \mathrm{~Bq}^{-1}\right.$ for ${ }^{226} \mathrm{Ra}, 6.9 \times 10^{-7} \mathrm{~Sv} \mathrm{~Bq}^{-1}$ for ${ }^{232} \mathrm{Th}, 1.3 \times 10^{-8} \mathrm{~Sv} \mathrm{~Bq}{ }^{-1}$ for ${ }^{137} \mathrm{Cs}$ and $6.2 \times 10^{-9} \mathrm{~Sv} \mathrm{~Bq}^{-1}$ for ${ }^{40} \mathrm{~K}$ ) [27-29].

The total dose (committed) via ingestion can be calculated using Equation 5:

$H_{\text {eff }}($ Total $)=E_{\text {eff }}\left({ }^{226} R a\right)+E_{\text {eff }}\left({ }^{232} T h\right)+E_{\text {eff }}\left({ }^{137} C s\right)+E_{\text {eff }}\left({ }^{40} K\right)$

To assess the lifetime cancer risk due to the ingestion of honey we used Equation 6:

$$
L_{C R}=A_{i r} * A_{i s} * R_{C}
$$

...where $\mathrm{L}_{C R}$ is the lifetime cancer risk, $\mathrm{A}_{i r}$ is annual intake of radionuclide $(\mathrm{Bq}), \mathrm{A}_{i s}$ is average span of life (78 y), and $\mathrm{R}_{\mathrm{c}}$ is mortality cancer risk coefficient $\left(\mathrm{Bq}^{-1}\right)$. The values of mortality cancer risk coefficients taken from the USEPA are $9.56 \times 10^{-9} \mathrm{~Bq}^{-1}$ for ${ }^{226} \mathrm{Ra}, 2.45 \times 10^{-9}$ $\mathrm{Bq}^{-1}$ for ${ }^{232} \mathrm{Th}, 6.88 \times 10^{-10} \mathrm{~Bq}^{-1}$ for ${ }^{137} \mathrm{Cs}$ and $5.89 \times 10^{-10} \mathrm{~Bq}^{-1}$ for ${ }^{40} \mathrm{~K}[30]$.

The honey samples collected from 30 locations were homogenized, weighed and transferred into uncontaminated empty cylindrical plastic containers of uniform size $(100 \mathrm{~mL})$. The samples were kept four weeks before analysis in airtight conditions to allow secular equilibrium between radium and thorium and their decay products.

The radioactivity concentration of every sample with relevant uncertainty was reported. The uncertainties of all measurements were calculated, taking into account statistical fluctuations of the peak, the backgrounds and efficiency calibration. Also, data were grouped according to collected samples in the seven regions of Kosovo. Arithmetical mean with relevant standard deviation, the minimum and maximum values are reported for every group. The activity concentration differences between the groups were calculated using statistical analysis method (one-way ANOVA). Differences were considered significant at $p<0.05$. Statistical analysis was performed using SPSS software version 21.0 (SPSS Inc., Chicago, IL).

\section{Results and Discussion}

The MDA for ${ }^{226} \mathrm{Ra},{ }^{232} \mathrm{Th},{ }^{40} \mathrm{~K}$ and ${ }^{137} \mathrm{Cs}$ radionuclides in the present measurement system are calculated as $0.33,0.38,2.36$ and $0.03 \mathrm{~Bq} \mathrm{~kg}^{-1}$, respectively. The activity concentrations of 19 samples $(63.3 \%)$ for ${ }^{226} \mathrm{Ra}$ radionuclide were found below the MDA. Again, the activity concentrations of 24 samples $(80 \%)$ for ${ }^{137} \mathrm{Cs}$ artificial radionuclide were either below the MDA or not detected.

The radioactivity results of the honey samples collected from 30 different locations are given in Table 1 for the natural radionuclides of ${ }^{226} \mathrm{Ra},{ }^{232} \mathrm{Th}$ and ${ }^{40} \mathrm{~K}$ and the artificial radionuclide of ${ }^{137} \mathrm{Cs}$. The radioactivity levels found for these honey samples are also shown in Fig. 2. The average activity concentrations of ${ }^{226} \mathrm{Ra},{ }^{232} \mathrm{Th},{ }^{40} \mathrm{~K}$ and ${ }^{137} \mathrm{Cs}$ radionuclides in the honey samples were $0.49 \pm 0.15 \mathrm{~Bq} \mathrm{~kg}^{-1}, 1.28 \pm 0.18 \mathrm{~Bq} \mathrm{~kg}^{-1}$, $20.44 \pm 0.69 \mathrm{~Bq} \mathrm{~kg}^{-1}$ and $1.03 \pm 0.11 \mathrm{~Bq} \mathrm{~kg}^{-1}$, respectively. The activity of ${ }^{40} \mathrm{~K}$ radionuclide is seen to be higher than ${ }^{226} \mathrm{Ra}$ and ${ }^{232} \mathrm{Th}$ radionuclides in all the studied honey samples. Because ${ }^{40} \mathrm{~K}$ is the dominant gamma emitter and it is always present in food, it may have negative consequences for the health of humans with long-duration irradiation and exposure [31]. Therefore, its evaluation for human health is important.

${ }^{137} \mathrm{Cs}$ is a radionuclide produced anthropogenically by several types of nuclear activity, including past testing of nuclear weapons, accidents in nuclear facilities, reprocessing of spent nuclear fuel and nuclear power reactors. ICRP permits the level of ${ }^{137} \mathrm{Cs}$ activity for foodstuffs as $1000 \mathrm{~Bq} \mathrm{~kg}^{-1}$ [32]. In this study, the active values of ${ }^{137} \mathrm{Cs}$ found in honey samples were well below the limit value. For this reason, we can suggest that the range of ${ }^{137} \mathrm{Cs}$ activity in the honey samples of this study is of no risk to public health. There is a wide variation of radioactivity concentration on different samples due to different environmental conditions. Artificial radionuclides identified in honey samples originated from past nuclear incidents that happened abroad, because there is no registered nuclear activity in Kosovo [14].

The radioactivity concentrations in the honey samples within seven regions (Ferzaj, Gjakova, Gjilan, Mitrovica, Peja, Pristina and Prizren) of Kosovo are given in Table 2. It was observed that the maximum activity concentrations were $0.73 \mathrm{~Bq} \mathrm{~kg}^{-1}$ in Pristina for ${ }^{226} \mathrm{Ra}, 3.43 \mathrm{~Bq} \mathrm{~kg}^{-1}$ in Peja for ${ }^{232} \mathrm{Th}, 2.80 \mathrm{~Bq} \mathrm{~kg}{ }^{-1}$ in Peja for ${ }^{137} \mathrm{Cs}$ and $91.84 \mathrm{~Bq} \mathrm{~kg}^{-1}$ in Peja for ${ }^{40} \mathrm{~K}$. As shown in Table 2, the highest mean concentrations for the studied radionuclides were observed in the Peja region except for ${ }^{226} \mathrm{Ra}$. As a result of the statistical analyses performed, no significant correlation $(p>0.05)$ was observed between the concentration differences in regions of Kosovo. 


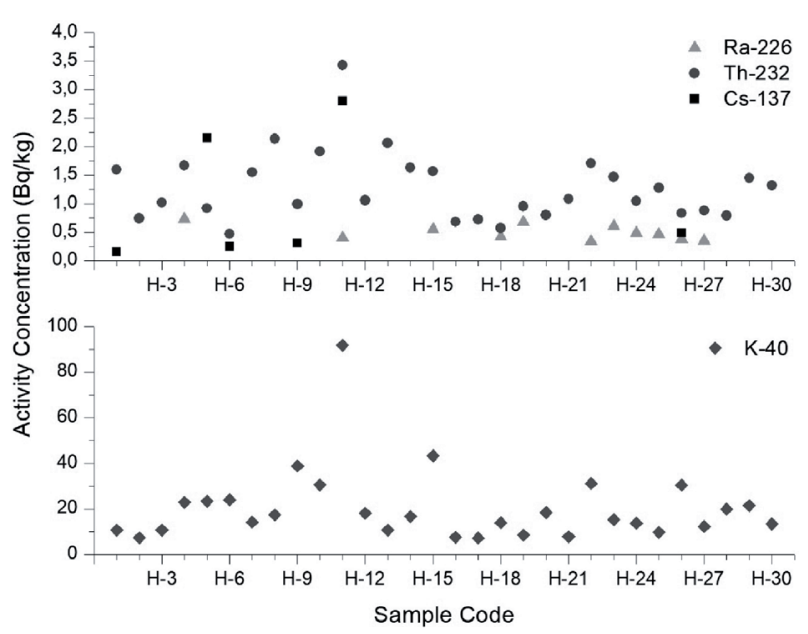

Fig. $2 .{ }^{226} \mathrm{Ra},{ }^{232} \mathrm{Th},{ }^{40} \mathrm{~K}$ and ${ }^{137} \mathrm{Cs}$ concentrations in the honey samples.

Calculated values of per capita daily intake for related radionuclides in the honey samples collected from the seven regions of Kosovo are presented in Fig. 3 and Table 3. The maximum and minimum values calculated for per capita daily intake were $145.96 \mathrm{mBq} \mathrm{d}^{-1}$ for ${ }^{40} \mathrm{~K}$ (Peja region) and $0.71 \mathrm{mBq} \mathrm{d}^{-1}$ for ${ }^{137} \mathrm{Cs}$ radionuclide (Mitrovica region).

The total committed effective dose and the annual effective doses taken by an individual via consumption

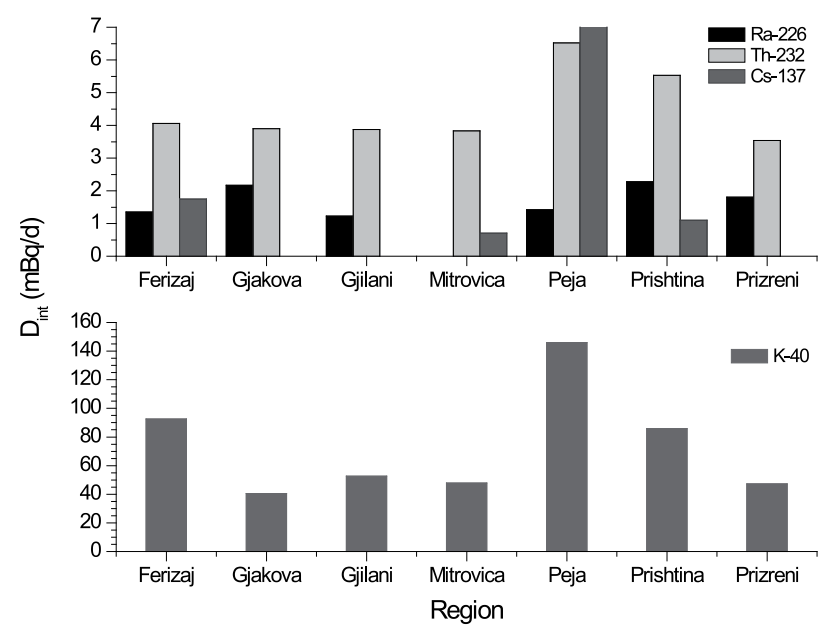

Fig. 3. Daily intake values calculated for studied radionuclides in the honey samples.

of honey are given in Table 3. The average annual effective doses calculated for ${ }^{226} \mathrm{Ra},{ }^{232} \mathrm{Th},{ }^{40} \mathrm{~K}$ and ${ }^{137} \mathrm{Cs}$ were found as $0.18,0.11,0.17$ and $0.02 \mu \mathrm{Sv} \mathrm{y}^{-1}$. The average total committed effective dose taken by an individual from ${ }^{226} \mathrm{Ra},{ }^{232} \mathrm{Th},{ }^{40} \mathrm{~K}$ and ${ }^{137} \mathrm{Cs}$ radionuclides via consumption of honey in Kosovo were found to be $1.45 \mu \mathrm{Sv} \mathrm{y}^{-1}$. The highest total committed effective dose was found for the Peje region $\left(2.16 \mu \mathrm{Sv} \mathrm{y}^{-1}\right)$. The global average annual radiation dose from the natural radiation

Table 2. Activity concentration values in the honey samples within regions of Kosovo.

\begin{tabular}{|c|c|c|c|c|}
\hline \multirow{3}{*}{ Region (N) } & \multicolumn{4}{|c|}{ Activity Concentrations (Bq/kg) } \\
\hline & ${ }^{226} \mathrm{Ra}$ & ${ }^{232} \mathrm{Th}$ & ${ }^{137} \mathrm{Cs}$ & ${ }^{40} \mathrm{~K}$ \\
\hline & $\begin{array}{c}\text { Mean } \\
\text { Minimum } \\
\text { Maximum }\end{array}$ & $\begin{array}{c}\text { Mean } \\
\text { Minimum } \\
\text { Maximum }\end{array}$ & $\begin{array}{c}\text { Mean } \\
\text { Minimum } \\
\text { Maximum }\end{array}$ & $\begin{array}{c}\text { Mean } \\
\text { Minimum } \\
\text { Maximum }\end{array}$ \\
\hline Ferizaj (2) & $\begin{array}{c}0.38 \pm 0.17 \\
<\text { MDA } \\
0.38\end{array}$ & $\begin{array}{c}1.14 \pm 0.18 \\
0.83 \\
1.45\end{array}$ & $\begin{array}{c}0.49 \pm 0.11 \\
<\mathrm{MDA} \\
0.49\end{array}$ & $\begin{array}{c}26.02 \pm 1.36 \\
21.54 \\
30.50\end{array}$ \\
\hline Gjakova (2) & $\begin{array}{c}0.61 \pm 0.19 \\
<\mathrm{MDA} \\
0.61\end{array}$ & $\begin{array}{c}1.10 \pm 0.13 \\
0.72 \\
1.47\end{array}$ & & $\begin{array}{c}11.36 \pm 0.33 \\
7.35 \\
15.37\end{array}$ \\
\hline Gjilani (4) & $\begin{array}{c}0.35 \pm 0.15 \\
<\mathrm{MDA} \\
0.35\end{array}$ & $\begin{array}{c}1.09 \pm 0.12 \\
0.68 \\
1.71 \\
\end{array}$ & & $\begin{array}{c}14.79 \pm 0.73 \\
7.62 \\
31.24 \\
\end{array}$ \\
\hline Mitrovica (5) & & $\begin{array}{c}1.08 \pm 0.16 \\
0.47 \\
1.60\end{array}$ & $\begin{array}{c}0.20 \pm 0.07 \\
<\mathrm{MDA} \\
0.25\end{array}$ & $\begin{array}{c}13.43 \pm 0.51 \\
7.37 \\
24.02\end{array}$ \\
\hline Peja (4) & $\begin{array}{c}0.40 \pm 0.19 \\
<\mathrm{MDA} \\
0.40\end{array}$ & $\begin{array}{c}1.83 \pm 0.32 \\
0.92 \\
3.43\end{array}$ & $\begin{array}{c}2.48 \pm 0.15 \\
<\mathrm{MDA} \\
2.80\end{array}$ & $\begin{array}{c}40.98 \pm 0.95 \\
18.12 \\
91.84\end{array}$ \\
\hline Prishtina (7) & $\begin{array}{c}0.64 \pm 0.16 \\
<\mathrm{MDA} \\
0.73\end{array}$ & $\begin{array}{c}1.55 \pm 0.16 \\
0.80 \\
2.14\end{array}$ & $\begin{array}{c}0.31 \pm 0.13 \\
<\text { MDA } \\
0.31\end{array}$ & $\begin{array}{c}24.09 \pm 0.73 \\
10.77 \\
43.36\end{array}$ \\
\hline Prizren (6) & $\begin{array}{c}0.51 \pm 0.13 \\
<\text { MDA } \\
0.67\end{array}$ & $\begin{array}{c}0.99 \pm 0.16 \\
0.57 \\
1.32\end{array}$ & & $\begin{array}{c}13.27 \pm 0.49 \\
8.67 \\
19.92\end{array}$ \\
\hline
\end{tabular}




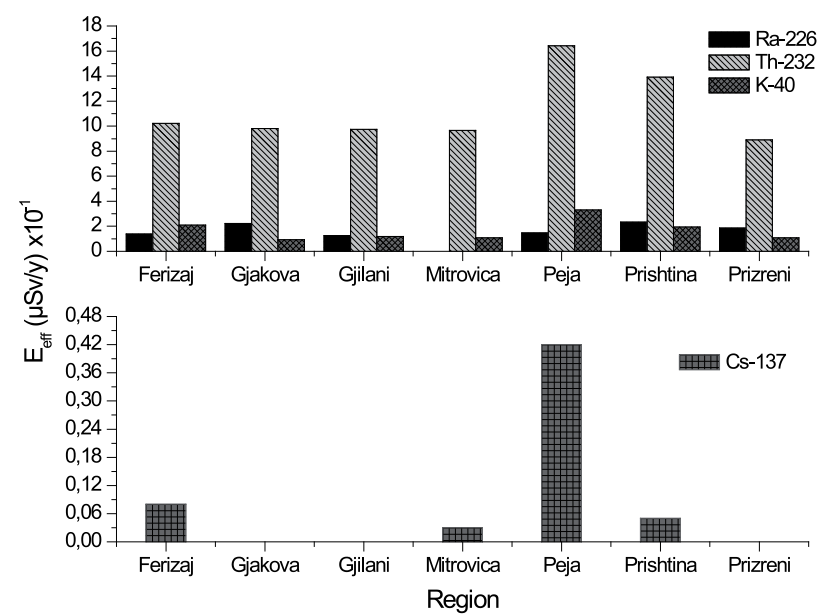

Fig. 4. Region-based annual effective dose values calculated for studied radionuclides.

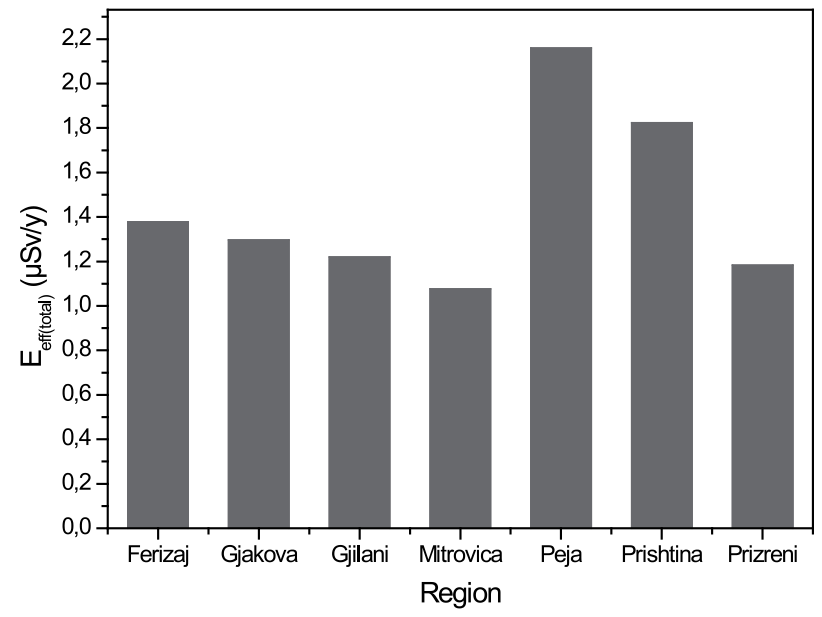

Fig. 5. Total annual region-based effective dose values taken by an individual via consumption of honey.

sources as proposed by UNSCEAR is $2400 \mu \mathrm{Sv} \mathrm{y}^{-1}$ [28]. The annual radiation dose value $\left(1.45 \mu \mathrm{Sv} \mathrm{y}^{-1}\right)$ founded in this study is lower than the global average
Table 4. Lifetime cancer risk values calculated for ${ }^{226} \mathrm{Ra},{ }^{232} \mathrm{Th}$, ${ }^{40} \mathrm{~K}$ and ${ }^{137} \mathrm{Cs}$ radionuclides.

\begin{tabular}{|c|c|c|c|c|}
\hline \multirow{2}{*}{ Region (N) } & \multicolumn{4}{|c|}{ Life time cancer risk } \\
\cline { 2 - 5 } & ${ }^{226} \mathrm{Ra}$ & ${ }^{232} \mathrm{Th}$ & ${ }^{137} \mathrm{Cs}$ & ${ }^{40} \mathrm{~K}$ \\
\hline Ferizaj (2) & 3.62 & 2.78 & 0.34 & 15.28 \\
\hline Gjakova (2) & 5.81 & 2.67 & & 6.67 \\
\hline Gjilani (4) & 3.29 & 2.66 & & 8.68 \\
\hline Mitrovica (5) & & 2.63 & 0.14 & 7.88 \\
\hline Peja (4) & 3.81 & 4.47 & 1.70 & 24.06 \\
\hline Prishtina (7) & 6.10 & 3.79 & 0.21 & 14.15 \\
\hline Prizreni (6) & 4.84 & 2.43 & & 7.80 \\
\hline
\end{tabular}

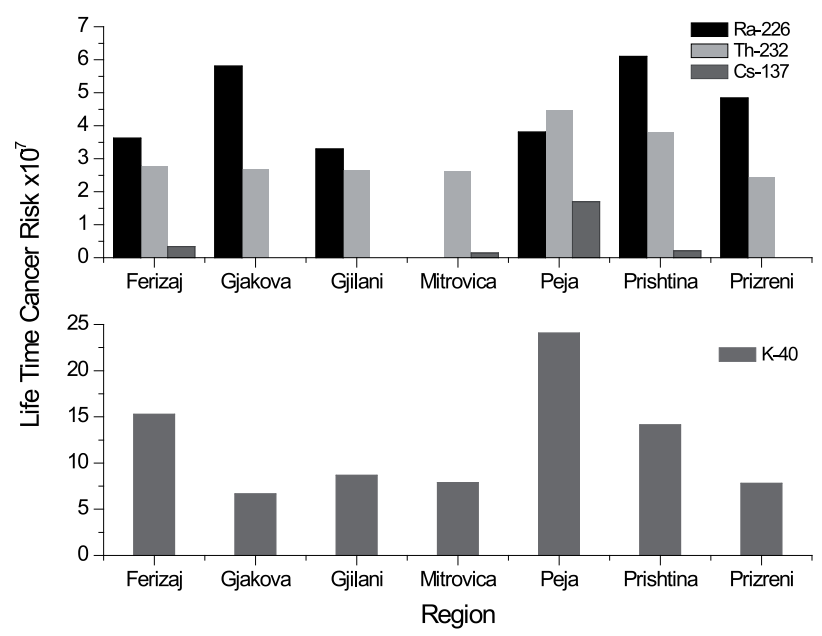

Fig. 6. Lifetime cancer risk values for studied radionuclides in the honeys in the regions of Kosovo.

annual radiation dose value $\left(2400 \mu \mathrm{Sv} \mathrm{y}^{-1}\right)$. Also, the contributions from the studied radionuclides were below the dose limit of $1 \mathrm{mSv} \mathrm{y}^{-1}$ as set in the ICRP recommendations for public exposure [33].

Table 3. Daily intake $\left(\mathrm{D}_{\text {int }}\right)$, annual effective dose $\left(\mathrm{E}_{\text {eff }}\right)$ and total committed effective dose $\left(\mathrm{E}_{\text {eff(total }}\right)$ values calculated for all studied radionuclides.

\begin{tabular}{|c|c|c|c|c|c|c|c|c|c|}
\hline \multirow{2}{*}{ Region (N) } & \multicolumn{4}{|c|}{$\mathrm{D}_{\text {int }}(\mathrm{mBq} / \mathrm{d})$} & \multicolumn{4}{|c|}{$\mathrm{E}_{\text {eff }}(\mu \mathrm{Sv} / \mathrm{y}) \times 10^{-1}$} & \multirow{2}{*}{$\begin{array}{l}E_{\text {eff(total }} \\
(\mu \mathrm{Sv} / \mathrm{y})\end{array}$} \\
\hline & ${ }^{226} \mathrm{Ra}$ & ${ }^{232} \mathrm{Th}$ & ${ }^{137} \mathrm{Cs}$ & ${ }^{40} \mathrm{~K}$ & ${ }^{226} \mathrm{Ra}$ & ${ }^{232} \mathrm{Th}$ & ${ }^{137} \mathrm{Cs}$ & ${ }^{40} \mathrm{~K}$ & \\
\hline Ferizaj (2) & 1.35 & 4.06 & 1.75 & 92.67 & 1.38 & 10.23 & 0.08 & 2.10 & 1.38 \\
\hline Gjakova (2) & 2.17 & 3.90 & & 40.46 & 2.22 & 9.82 & & 0.92 & 1.30 \\
\hline Gjilani (4) & 1.23 & 3.87 & & 52.66 & 1.26 & 9.75 & & 1.19 & 1.22 \\
\hline Mitrovica (5) & & 3.83 & 0.71 & 47.82 & & 9.65 & 0.03 & 1.08 & 1.08 \\
\hline Peja (4) & 1.42 & 6.52 & 8.82 & 145.96 & 1.46 & 16.42 & 0.42 & 3.30 & 2.16 \\
\hline Prishtina (7) & 2.28 & 5.53 & 1.10 & 85.81 & 2.33 & 13.92 & 0.05 & 1.94 & 1.82 \\
\hline Prizreni (6) & 1.81 & 3.54 & & 47.27 & 1.85 & 8.91 & & 1.07 & 1.18 \\
\hline
\end{tabular}


Table 5. Comparison of published activity results for honey samples.

\begin{tabular}{|c|c|c|c|c|c|}
\hline \multirow{2}{*}{ Region } & \multicolumn{3}{|c|}{ Activity Concentrations $(\mathrm{Bq} / \mathrm{kg})$} & \multirow{2}{*}{ Reference } \\
\cline { 2 - 5 } & ${ }^{226} \mathrm{Ra}$ & ${ }^{232} \mathrm{Th}$ & ${ }^{137} \mathrm{Cs}$ & ${ }^{40} \mathrm{~K}$ & \multirow{2}{*}{ (Meli et al., 2016) } \\
\hline Italy & $<0.3$ & & $<0.1$ & 28.1 & (Esposito et al., 2002) \\
\hline Yuguslavia & $<2.8$ & $<2.2$ & $<1.7$ & $<87$ & (Borawska et al., 2013) \\
\hline Poland & & & 1.3 & 36.1 & (Djuric et al., 1996) \\
\hline West Serbia & & 0.26 & 2.4 & 27.1 & (Barišić et al., 1999) \\
\hline Croatia & & & 0.4 & 28.3 & (Altekin et al., 2015) \\
\hline Turkey & & & 18.2 & 68.5 & This study \\
\hline Kosovo & 0.5 & 1.3 & 1.0 & 20.4 & \\
\hline
\end{tabular}

The lifetime cancer risk values calculated for ${ }^{226} \mathrm{Ra}$, ${ }^{232} \mathrm{Th},{ }^{40} \mathrm{~K}$ and ${ }^{137} \mathrm{Cs}$ radionuclides in the honey samples are given in Table 4 . The lifetime cancer risk was found to vary from $3.29 \times 10^{-7}$ to $6.10 \times 10^{-7}$ for ${ }^{226} \mathrm{Ra}, 2.43 \times 10^{-7}$ to $4.47 \times 10^{-7}$ for ${ }^{232} \mathrm{Th}, 6.67 \times 10^{-7}$ to $24.06 \times 10^{-7}$ for ${ }^{40} \mathrm{~K}$ and $0.14 \times 10^{-7}$ to $1.70 \times 10^{-7}$ for ${ }^{137} \mathrm{Cs}$, which are low compared with the acceptable cancer risk of $10^{-3}$ for radiological risk $[34,35]$.

The average radioactivity results obtained in this study are compared with those reported in the literature for honey samples collected from different countries in Table 5, which shows that our values are similar to the other values except for Turkey.

\section{Conclusions}

To assess the internal dose of radionuclides taken in by food, the activity of each radionuclide in food and water has to be measured. Since honey is a nutrient widely consumed in human life, determining the radioactivity in its content is very important. Within this scope, the natural $\left({ }^{226} \mathrm{Ra},{ }^{232} \mathrm{Th}\right.$ and $\left.{ }^{40} \mathrm{~K}\right)$ and artificial radioactivity $\left({ }^{137} \mathrm{Cs}\right)$ levels in 30 honey samples collected from regions of Kosovo were determined by a highpurity germanium detector. For each of the collected honey samples, specific activity, daily intake $\left(\mathrm{D}_{\text {int }}\right)$, annual effective dose $\left(\mathrm{E}_{\text {eff }}\right)$, total committed effective dose $\left(\mathrm{E}_{\text {eff }}(\right.$ total $\left.)\right)$ and lifetime cancer risk values $\left(\mathrm{L}_{C R}\right)$ values were calculated.

The average activity concentrations of ${ }^{226} \mathrm{Ra},{ }^{232} \mathrm{Th}$, ${ }^{137} \mathrm{Cs}$ and ${ }^{40} \mathrm{~K}$ radionuclides in the 30 investigated honey samples were found to be $0.49 \pm 0.15,1.28 \pm 0.18$, $1.03 \pm 0.11$ and $20.44 \pm 0.69 \mathrm{~Bq} \mathrm{~kg}^{-1}$, respectively. $20 \%$ of 30 honey samples were found to be still contaminated with artificial isotope ${ }^{137} \mathrm{Cs}$. Nevertheless, the activity values of ${ }^{137} \mathrm{Cs}$ found in honey samples were well below the limit value $\left(1000 \mathrm{~Bq} \mathrm{~kg}^{-1}\right)$ recommended by the ICRP in foodstuffs. Radioactivity concentrations in the honey samples, collected in all regions of Kosovo, were examined and it was observed that the maximum activity concentrations were: $0.73 \mathrm{~Bq} \mathrm{~kg}^{-1}$ in Prishtina for ${ }^{226} \mathrm{Ra}, 3.43 \mathrm{~Bq} \mathrm{~kg}{ }^{-1}$ in Peja for ${ }^{232} \mathrm{Th}$,
2.80 Bq kg-1 in Peja for ${ }^{137} \mathrm{Cs}$ and $91.84 \mathrm{~Bq} \mathrm{~kg}^{-1}$ in Peja for ${ }^{40} \mathrm{~K}$.

The total committed effective dose and the annual effective doses taken by an individual via consumption of honey were calculated. The annual radiation dose value $\left(1.45 \mu \mathrm{Sv} \mathrm{y}^{-1}\right)$ founded in this study is lower than the global average annual radiation dose value $\left(2400 \mu \mathrm{Sv}^{-1}\right)$. Also, the contributions from the studied radionuclides were below the dose limit of $1 \mathrm{mSv} \mathrm{y}^{-1}$ as set in the ICRP recommendations for public exposure. The lifetime cancer risk for the honeys was found to vary from $3.29 \times 10^{-7}$ to $6.10 \times 10^{-7}$ for ${ }^{226} \mathrm{Ra}, 2.43 \times 10^{-7}$ to $4.47 \times 10^{-7}$ for ${ }^{232} \mathrm{Th}, 6.67 \times 10^{-7}$ to $24.06 \times 10^{-7}$ for ${ }^{40} \mathrm{~K}$ and $0.14 \times 10^{-7}$ to $1.70 \times 10^{-7}$ for ${ }^{137} \mathrm{Cs}$, and these values are lower than the acceptable cancer risk of $10^{-3}$ for radiological risk.

As a result, this study shows that the investigated honey samples in Kosovo can be consumed with peace of mind without any radiological hazards. Also, this study can be used as a reference for future studies.

\section{Conflict of Interest}

The authors report no conflicts of interest.

\section{Formatting of Funding Sources}

This research did not receive any specific grant from funding agencies in the public, commercial or not-forprofit sectors.

\section{References}

1. MEO S.A., AL-ASIRI S.A., MAHESAR A.L., ANSARI M.J. Role of honey in modern medicine. Saudi Journal of Biological Sciences, 24 (5), 975, 2017.

2. RAO P.V., KRISHNAN K.T., SALLEH N., GAN S.H. Biological and therapeutic effects of honey produced by honey bees and stingless bees: a comparative review. Revista Brasileira de Farmacognosia, 26 (5), 657, 2016. 
3. BUENO-COSTA F.M., ZAMBIAZI R.C., BOHMER B.W., CHAVES F.C., SILVA W.P.D.A, ZANUSSO J.T., DUTRA I. Antibacterial and antioxidant activity of honeys from the state of Rio Grande do Sul, Brazil. LWT - Food Science and Technology, 65, 333, 2016.

4. DA SILVA I.A.A., DA SILVA T.M.S., CAMARA C.A., QUEIROZ N., MAGNANI M., DE NOVAIS J.S., SOLEDADE L.E.B., LIMA E.O., DE SOUZA A.L., DE SOUZA A.G. Phenolic profile, antioxidant activity and palynological analysis of stingless bee honey from Amazonas, Northern Brazil. Food Chemistry, 141 (4), 3552, 2013.

5. KHALIL A.T., KHAN I., AHMAD K., KHAN Y.A., KHAN J., SHINWARI Z.K. Antibacterial activity of honey in north-west Pakistan against select human pathogens. Journal of Traditional Chinese Medicine, 34 (1), 86, 2014

6. FOGH S., DESHMUKH S., BERK L.B., DUECK A.C., ROOF K., YACOUB S., GREG T., STEPHANS K., RIMNER A., DE NITTIS A., PABLO J., RINEER J., WILLIAMS T.M., BRUNER D. A Randomized Phase 2 Trial of Prophylactic Manuka Honey for the Reduction of Chemoradiation Therapy-Induced Esophagitis During the Treatment of Lung Cancer: Results of NRG Oncology RTOG 1012. International Journal of Radiation Oncology*Biology*Physics, 97 (4), 786, 2017.

7. XU J.-L., XIA R., SUN Z.-H., SUN L., MIN X., LIU C., ZHANG H., ZHU Y.-M. Effects of honey use on the management of radio/chemotherapy-induced mucositis: a meta-analysis of randomized controlled trials. International Journal of Oral and Maxillofacial Surgery, 45 (12), 1618, 2016.

8. MCLOONE P., WARNOCK M., FYFE L. Honey: a realistic antimicrobial for disorders of the skin. Journal of Microbiology, Immunology and Infection, 49 (2), 161, 2016.

9. LAMBERT O., PIROUX M., PUYO S., THORIN C., LARHANTEC M., DELBAC F., POULIQUEN H. Bees, honey and pollen as sentinels for lead environmental contamination. Environmental Pollution, 170, 254, 2012.

10. MATIN G., KARGAR N., BUYUKISIK H. B. Biomonitoring of cadmium, lead, arsenic and mercury in industrial districts of Izmir, Turkey by using honey bees, propolis and pine tree leaves. Ecological Engineering, 90, 331, 2016.

11. ESCUREDO O., MÍGUEZ M., FERNÁNDEZGONZÁLEZ M., CARMEN SEIJO M. Nutritional value and antioxidant activity of honeys produced in a European Atlantic area. Food Chemistry, 138 (2), 851, 2013.

12. SCHEIBEL V., APPOLONI C.R., SCHECHTER H. Natural radioactivity traces in South-Brazilian cereal flours by gamma-ray spectrometry. Journal of Radioanalytical and Nuclear Chemistry, 270 (1), 163, 2006.

13. HERRERO-LATORRE C., BARCIELA-GARCÍA J., GARCÍA-MARTÍN S., PEÑA-CRECENTE R.M. The use of honeybees and honey as environmental bioindicators for metals and radionuclides: a review. Environmental Reviews, 25 (4), 463, 2017.

14. HODOLLI G., KADIRI S., DUMANI S., HALIMI Y., JONUZAJ A., XHAFA B., HASANI F. Variation of total beta activity in air by years on Obiliq. Journal of Environmental and Occupational Science, 1 (2), 121, 2012.

15. ALTEKIN E., DIZMAN S., KESER R. Radioactivity and heavy metal concentrations in various honey samples. Journal of Environmental Protection and Ecology, 16 (2), 716, 2015.
16. MELI M.A., DESIDERI D., ROSELLI C., FEDUZI L., BENEDETTI C. Radioactivity in honey of the central Italy. Food Chemistry, 202, 349, 2016.

17. MOLZAHN D., ASSMANN-WERTHMÜLLER U. Caesium radioactivity in several selected species of honey. Science of the total environment, 130, 95, 1993.

18. ALMEIDA-SILVA M., CANHA N., GALINHA C., DUNG H.M., FREITAS M.C., SITOE T. Trace elements in wild and orchard honeys. Applied Radiation and Isotopes, 69 (11), 1592, 2011.

19. GRIGORESCU E.L., CRISTINA RAZDOLESCU, A., SAHAGIA M., LUCA A., IVAN C., TANASE G. Standardization of 152Eu. Applied Radiation and Isotopes, 56 (1), 435, 2002.

20. IAEA. Measurement of radionuclides in food and the environment, 295, 1989.

21. ICRP. 1990 Recommendations of the International Commission on Radiological Protection (No. ICRP Publication 60, Ann. ICRP 21 (1-3)). 1990.

22. IAEA. Measurement of Radionuclides in Food and the Environment. Retrieved from http://www-pub.iaea.org/ books/IAEABooks/1398/Measurement-of-Radionuclidesin-Food-and-the-Environment 1989.

23. CURRIE L.A. Limits for qualitative detection and quantitative determination. Application to radiochemistry. Analytical Chemistry, 40 (3), 586, 1968.

24. ZARE M.R., KAMALI M., OMIDI Z., KHORAMBAGHERI M., MORTAZAVI M.S., EBRAHIMI M., AKBARZADEH G. Evaluation of natural radioactivity content in high-volume surface water samples along the northern coast of Oman Sea using portable high-resolution gamma-ray spectrometry. Journal of Environmental Radioactivity, 144, 134, 2015.

25. KHANDAKER M.U., WAHIB N.B., AMIN Y.M., BRADLEY D.A. Committed effective dose from naturally occuring radionuclides in shellfish. Radiation Physics and Chemistry, 88, 1, 2013.

26. Ministry of Agriculture, Foresty and Rural Developement, \& Republic of Kosovo. Green Report Kosovo 2016 (p. 167). Pristina 2016. Retrieved from http://www.mbpzhrks.net/repository/docs/Green_Report_Kosovo_2016_ Final_050417.pdf 2016.

27. $\operatorname{IAEA}^{-}$(Ed.). Radiation protection and safety of radiation sources: International basic safety standards; general safety requirements (Interim ed.). Vienna: International Atomic Energy Agency. 2011.

28. UNSCEAR. Exposures from Natural Radiation Sources. (No. Annex-b) (p. 140). New York: UNSCEAR. 2000.

29. ICRP. Age-dependent Doses to Members of the Public from Intake of Radionuclides - Part 2 Ingestion Dose Coefficients (No. ICRP Publication 67, Ann. ICRP 23 (3-4)). 1994.

30. US EPA. Cancer Risk Coefficients for Environmental Exposure to RAdionuclides (No. Federal Guidance Report No. 13). Retrieved from https:/www.epa.gov/sites/ production/files/2015-05/documents/402-r-99-001.pdf 1999.

31. KHANDAKER M.U., JOJO P.J., KASSIM H.A., AMIN Y.M. Radiometric analysis of construction materials using HPGe gamma-ray spectrometry. Radiation Protection Dosimetry, 152 (1-3), 33, 2012.

32. ICRP. Protecting people against radiation exposure in the event of a radiological attack (No. ICRP Publication 96, Ann. ICRP Final TG draft.). Ottawa. 2004.

33. ICRP. The 2007 Recommendations of the International Commission on Radiological Protection (No. ICRP Publication 103). 2007. 
34. ASADUZZAMAN K., KHANDAKER M.U., AMIN Y.M., MAHAT R. Uptake and distribution of natural radioactivity in rice from soil in north and west part of peninsular malaysia for the estimation of ingestion dose to man. Annals of Nuclear Energy, 76, 85, 2015.)
35. PATRA A.C., MOHAPATRA S., SAHOO S.K., LENKA P., DUBEY J.S., TRIPATHI R.M., PURANIK V.D. Agedependent dose and health risk due to intake of uranium in drinking water from Jaduguda, India. Radiation Protection Dosimetry, 155 (2), 210, 2013. 